\title{
Territorial dynamics and boundary effects in a protected area of the Central Iberian Peninsula
}

Research Article

Paloma de las Heras ${ }^{1 *}$, Paloma Fernández-Sañudo², Nieves López-Estébanez ${ }^{3}$, María José Roldán²

1 Ecology Department, Biology Faculty, Complutense University, Madrid

2 Madrid Regional Government Environmental Research Centre

3 Geography Department, Autónoma University, Madrid

Received 28 June 2010; accepted 19 September 2010

Abstract: We analysed the main changes in land use over a 21 year period within the perimeter of a Protected Natural Area (PNA) and outside this perimeter. The area is characterised by its Mediterranean mid-mountain landscape and its piedmont, which extends almost as far as the city of Madrid. We employed cartography of land use and plant formation from 1980 and 2001. We identified land uses and their changes in this time period in order to determine the principal territorial dynamics (scrub encroachment, urban development, forest encroachment, new pastures and new crops). Subsequently, we performed a comparative analysis between the changes inside and those outside the protected area. The results show that there is a boundary effect between the protected area and the surrounding zone, which is more notable in the areas where urban development has intensified. This kind of research serves to establish whether or not a PNA contributes to protecting and conserving natural resources as compared to what occurs in the unprotected surrounding area, which tends to be subjected to more aggressive dynamics.

Keywords: land-use change $\cdot$ Protected Natural Area $\cdot$ Mediterranean landscape $\cdot$ Spain

(C) Versita Sp. z o.o.

\section{Introduction}

The Mediterranean landscape presents both natural dynamic processes and those induced directly or indirectly by human activities -agricultural, industrial, urban, etc.-, which can cause to environmental problems. To the extent that these problems are defined with greater accuracy,

*E-mail: pheras@bio.ucm.es protected areas can effectively contribute to the objectives of conservation of biological diversity, to attenuating the negative effects of global change and to improving the population's quality of life $[1,2]$. In this sense, there has been an increase in the number of Protected Natural Areas (PNA) in Europe [3], and there is a need to assess the effects of their establishment and management on different territories.

In areas of the Mediterranean region in Spain, landscapes created following the traditional use of resources through agriculture-forestry-pasture practices have been the sub- 


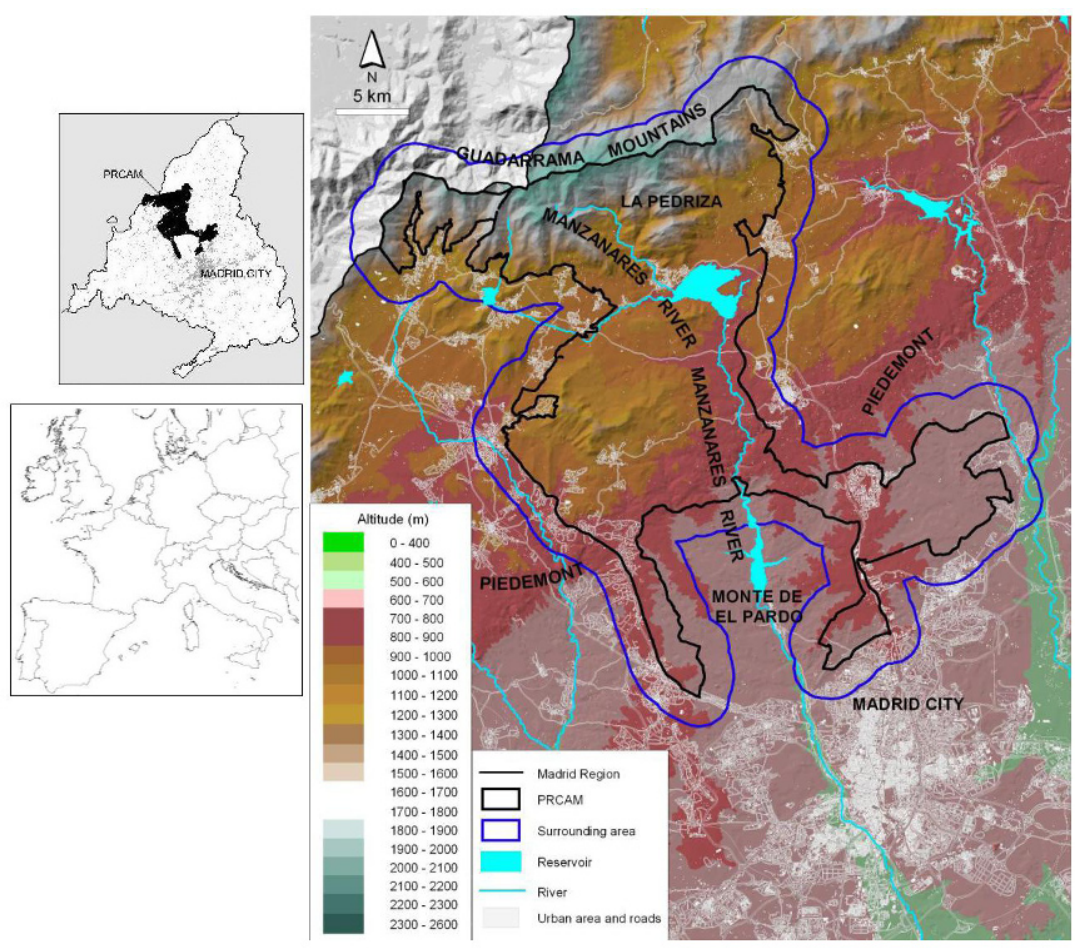

Figure 1. Location of the study area.

ject of special conservation interest for its contribution to the maintenance of biodiversity and efficient use of natural resources [4]. However, the conservation of the natural environment and of traditionally managed ecosystems should not constitute the only objective of PNA. Consideration should also be given to metropolitan environments and other sectors of activity, which can constitute a threat to conservation if they are not suitably managed [5]. Many of the ecological processes taking place therein depend upon horizontal flows (water, nutrient, energy, species) connecting different areas. Little is yet known of these processes, particularly at regional scale, despite the fact that they play a vital role in territorial configuration and are a key factor in nature conservation $[6,7]$. Consequently, territorial management is important, not only for the maintenance of ecological processes or species distribution, but also because it determines the landscape structure and constitutes an indicator of the diversity and intensity of land uses within the territory [8].

In Spain, the growing demand for land, mainly for urban development, has in some cases led to the declaration of PNA as a tool for protecting resources and traditional land uses in certain areas and exclusively within their limits. Several studies, however, indicate that merely considering isolated areas is ineffective with regard to reaching protection objectives if the ecological processes occurring outside are not also considered [8-13].

Merely protecting land does not ensure improved protection of the territory, as this does not necessarily involve more effective land management [14-16]. This is because PNA are not isolated zones, but rather interact with the surrounding areas. Furthermore, they are sensitive to large-scale socioeconomic and territorial dynamics [1719]. Few studies exist, however, on the boundary effect. In this study, 'boundary effect' is understood as the different distribution of land use types and territorial dynamics (land use change) within and outside the protected zone [5].

The Madrid region lies in the centre of the Iberian Peninsula and has over 6 million inhabitants. Since half-way through the last century, there has been an intense process of change in land uses. The process of abandonment of agricultural activities and the migration of the rural population towards the city, common to other European rural areas throughout the $20^{\text {th }}$ century [20-23], has gone hand in hand with intense socioeconomic development in the region. This development is fundamentally related to the service sector, which currently dominates Madrid's economy and requires increasingly more land for urban development. This reduces the amount of land available 
for other activities, particularly agriculture [16]. In the Madrid region, PNA (including Sites of Community Importance) occupy $40 \%$ of the territory.

This study attempts to evaluate the extent to which a PNA acts as a tool for protecting not only the protected zone, but also the surrounding area. To this end, we analysed whether the processes taking place inside the boundaries correspond with those occurring outside and whether there is a boundary effect between both zones and its consequences on the territory.

\section{Study area}

We conducted our study in the Parque Regional de la Cuenca Alta del Manzanares (PRCAM - Upper Manzanares River Basin Regional Park) and the surrounding area. The PRCAM is located in the centre of the Iberian Peninsula, within the Madrid Regional Autonomy and approximately $50 \mathrm{~km}$ to the northwest of the city (Figure 1). It is characterised by a mid-mountain Mediterranean landscape, with altitudes ranging from $660 \mathrm{~m}$ to $2,200 \mathrm{~m}$. The area covers the southern slopes of the Guadarrama Mountains. The gneissic summit presents high-altitude pastures of Festuca curvifolia and shrubs of Cytisus oromediterraneus. Within PRCAM there is one of Europe's most important granite landscapes, "La Pedriza", a protected area since 1930. The dominant plant formations comprise oak forests (Quercus pyrenaica) and repopulated pine forests (Pinus sylvestris). The piedmont in the eastern sector comprises detritic materials with cereal crops and pastures. In the central and western sectors gneissic and granitic piedmont presents dehesas of Holm oak (Quercus ilex ssp. Ballota). To the south it joins with the sedimentary basin of the Tajo river, where cereal crops predominate, alternating with Holm oak forests. The PRCAM became protected in the 1980s and covers an area of 52,939 ha.

In order to conduct our comparative study of changes in land use over time, we automatically mapped a $2 \mathrm{~km}-$ wide zone around the Park perimeter, whose total area is 44,499 ha. We considered that the width used was the most adequate for recognising different territorial dynamics outside of PNA, without overlapping other nearby protected areas, administrative regions or geomorphologic units.

\section{Material and methods}

\subsection{Analysis of changes in land use. Territo- rial dynamics}

We designed two maps of land use and vegetation, one corresponding to 1980 and another to 2001 for PRCAM and the surrounding area. To this end we employed orthorectified aerial photography from a 1980 flight at a scale of 1:18,000 and orthophotography from 2001 at a resolution of $2.5 \mathrm{~m}$ (provided by Madrid Regional Government Cartographic Service). We performed the photo interpretation considering the scale of least resolution (i.e., the aerial photography) in order for both maps to be comparable. The minimum cartographic unit was 0.61 ha (Figure 2a).

To set the first classification of vegetation types and land use in the 2001 orthophotography and in the 1980 aerial photograph, polygons were distinguished by color, texture, density, etc. [24]. Likewise, we considered other pre-existing vegetation and land-use maps for the Madrid Regional Autonomy [25-27] and data from the experts consulted. In order to eliminate potential errors, characteristic locations of each type of vegetation or land use were chosen for checking against the map data available. The polygons that could not be assigned to the classes established were checked using field work. These field surveys were conducted extensively throughout the months of May and June 2005, taking more than 700 panoramic pictures. Thus it was possible to assign a vegetation type or land use to each polygon based on their appearance (Figure 2b).

Finally, in order to simplify the analysis and make it comparable with similar works being done in other PNAs, vegetation types and land uses were grouped into the fewest number of simple categories possible. The criterion was the biotype. These categories are shown in Table 1. We did not distinguish the different degrees of forest or scrub density, or the age of the reforestations. It was interesting, however, to highlight the degree of consolidation of the urban areas and of those susceptible to urban development, as this is one of the aspects showing most variation in the Madrid region since the 1970s.

We then crossed the land-use maps of 1980 and 2001 by means of techniques of overlap and digital layer intersection with GIS software, thus comparing the information from both years. The result was a new map on which each polygon showed the land use observed in both years. Thus, we identified all the types of changes that had taken place both in the PNA and in the surrounding area during the 21-year period. Then it is possible to know if each type of vegetation or land use in each part of the terri- 

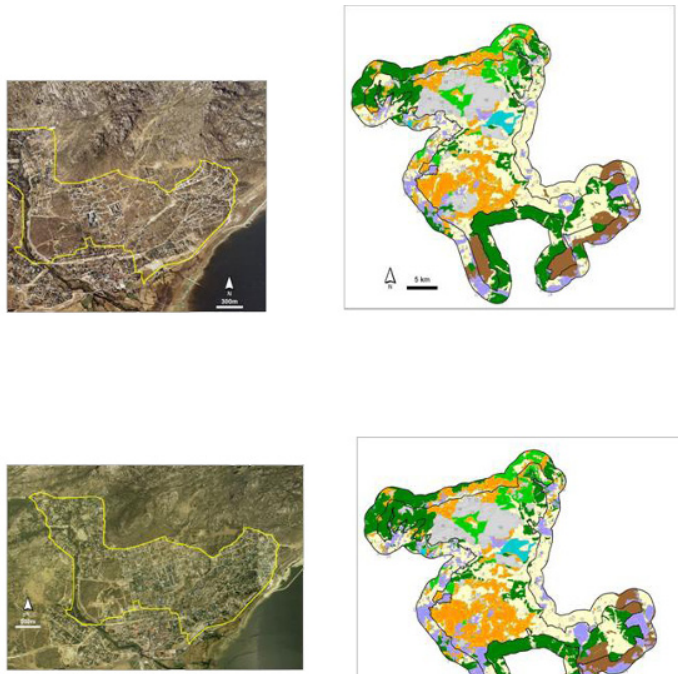

a)

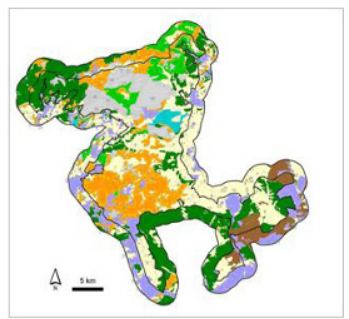

b)

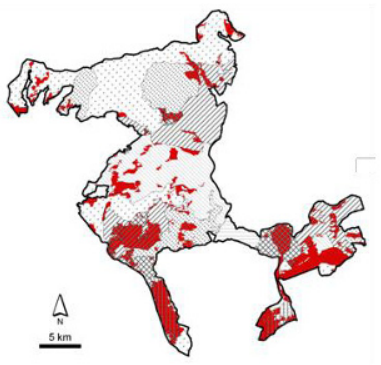

c)

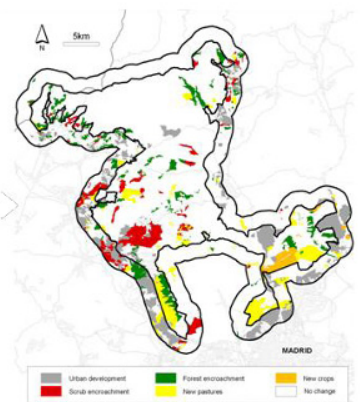

d)

Figure 2. Methodological procedure applied for the land uses dynamics analysis.

tory has changed or not. The changes identified (18) were classified and simplified into types of dynamics (Figure 2c and d).

Finally, in order to know the importance of each type of dynamic, we calculated the percentage area of each over the total area of the Park as well as over the area of the Park that had changed. These two percentages were calculated also for the surrounding area. We express this information cartographically (Figure 2d).

\subsection{Study of the boundary effect}

For the years considered (1980 and 2001) we compared land uses inside the PRCAM with those in the surrounding area. We also analysed the territorial dynamics over time in both zones in order to determine whether the edges of the Park caused a "boundary effect" on the surrounding area.

We first considered contacts between land use located inside and outside the PNA, which enabled us to detect the continuity or discontinuity of the polygon of different land uses or plant formations.

We then compared the area of each land use within the park and the surrounding area each year by applying a Chi Square analysis $\left(\chi^{2}\right)$, which showed whether or not there was any association between land use and zones. Finally, we evaluated the differences that might be caused by the boundary of the PNA in the territorial dynamics, analysing the frequencies of each type of territorial dy- namics, both inside and outside the park. In order to establish whether they are preferentially associated with one location or another, we applied another Chi Square analysis $\left(\chi^{2}\right)$.

\section{Results and discussion}

\subsection{Diachronic analysis of land uses}

We obtained two diachronic maps showing different scenarios relating to land use in this territory in 1980 and in 2001, differentiating 8 types (Table 1, Figure 3).

Within the park, in both years, the most abundant type of land use is pasture (Figure 4), which reflects the importance of extensive livestock farming in this area. Nature conservation in Spain should involve protection and conservation of these traditional agrosilvopastoral systems $[28,29]$. An essential ecological feature of this kind of system involves a high level of efficiency in energy and nutrient use. As a result, the use of land resources is optimized and the rural activities are adapted to natural production cycles $[30,31]$.

The next most abundant types of land use by extension are forest, scrub and rocky areas with scrub and trees. These are all characteristics of this PNA, although the latter comprises this territory's unique landscape.

We found no noteworthy changes in number of land uses or in the typology thereof within the park. We can only 


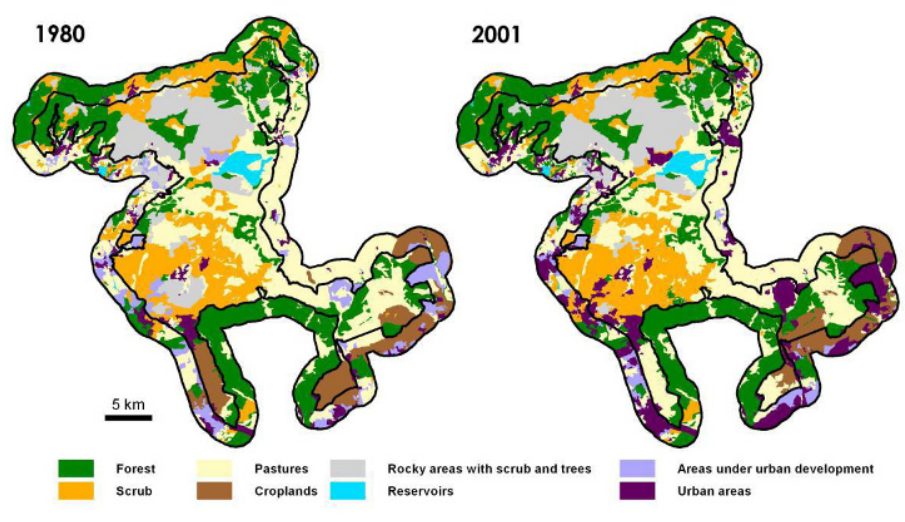

Figure 3. Map of types of land use and vegetation units in the PRCAM and in the surrounding area in 1980 and in 2001.

highlight the absence in 2001 of "areas under urban development" as those identified in 1980 have now become consolidated urban areas (Figure 3). The land uses showing the biggest increase in extension are scrub, tree formations and urbanised areas, whereas croplands show a decrease (Figure 4).

In the surrounding area, the most common land uses are forest, pastures and urbanised areas. Some of the pastures mapped in this sector (southern zone) correspond to abandoned agricultural areas and areas recently colonized by therophyte. The rest have been created by traditional livestock farming that remain conserved in the surrounding area, as well as inside the PRCAM. Both types of pastures, however, fall within the same category in the land-use cartography. Moreover, we detected no changes in land use richness (number of land use types), thus the same types identified in 1980 remain in 2001 . Whereas no change in forest extension has occurred, there has been a decrease in pastures and an increase in urbanised areas (Figure 4).

\subsection{Analysis of the boundary effect on vege- tation and land uses}

In 1980, the analysis of the continuity or discontinuity of the polygons on both sides of the boundary of the park showed that, in the northern sector, the patches of scrub (Cytisus oromediterraneus) and forests (Pinus sylvestris) remained continuous (Figure 3 ). This occurs in high altitude zones, which are quite well conserved with plant formations characteristic of Mediterranean high mountain. In the eastern sector-detritic piedmont- continuity can also be seen in some land uses inside and outside the protected area, with a noteworthy presence of pastures. This result once again reflects the importance of livestock farming in this territory [32].

The differences observed in the southern sector-scrub and pastures inside the PNA compared with dense Holm oak outside the Park- are attributable to the presence of the Monte de El Pardo. This is a Holm oak forest historically belonging to the Royal Family and now managed by the National Trust as a Natural Reserve. In the south-western sector-granite piedmont- a greater discontinuity of land use can be observed, as occurs with croplands within the PNA adjacent to pastures and urbanised areas in the surrounding area.

In general terms, the differences between zones (inside/outside the PNA) in 2001 become more accentuated than in 1980, and a more evident discontinuity of land uses can be observed. This was brought about by the existence of the park itself, where urban land use is regulated (Figure 3). In general, in the study area, traditional uses are abandoned to a certain extent, which gives rise to the spread of natural plant formations (scrub and forest). The northern and northwestern boundaries present the highest level of continuity mainly due to their orographic features, as these sectors are at higher altitudes, where the natural values of the park as a whole are best conserved (as mentioned above). The southern sector maintains the historic difference in landscapes caused by the presence of the Monte de El Pardo. In the western and southeastern areas, there is an evident boundary effect, where the natural vegetation -forest, scrub and pasture- inside limit with urbanised areas outside. Thus, there is a juxtaposition of natural and traditional land uses inside the PRCAM and the urban areas in the surrounding zone. So the urban development outside the protected area has consolidated the boundary effect with regard to land use in much of the park.

The results of the Chi Square analysis $\left(x^{2}\right)$ indicate that in 

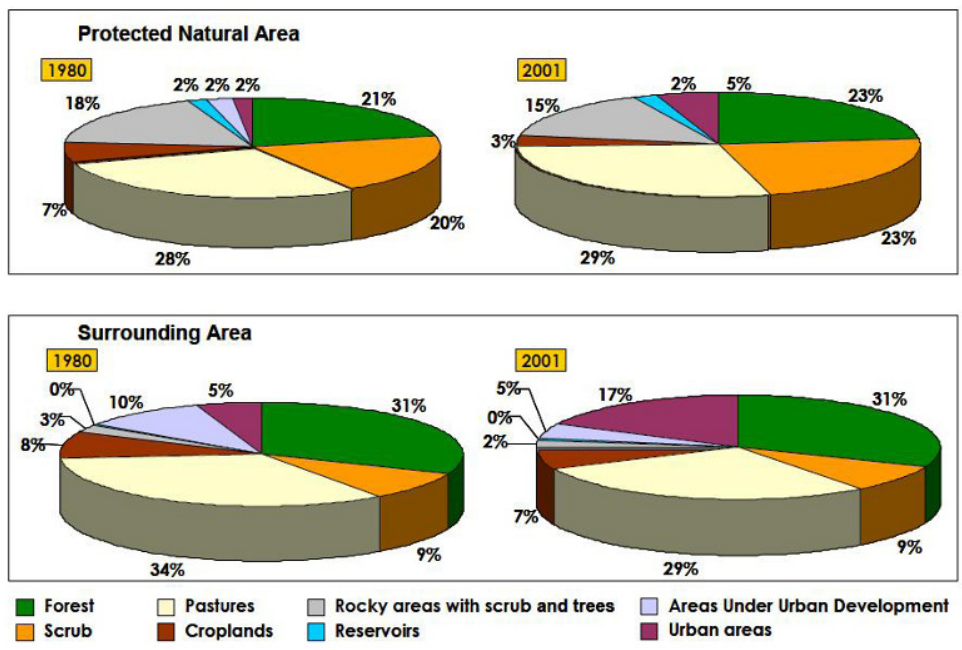

Figure 4. Percentage of area occupied by each type of land use in the PRCAM and in the surrounding area in 1980 and 2001.

Table 1. Classification and description of the eight land uses and vegetation types in the study area.

\begin{tabular}{|c|c|}
\hline TYPES & DESCRIPTION \\
\hline \multirow[t]{3}{*}{ FOREST } & $\begin{array}{l}\text { All formations of deciduous leafy tree species } \\
\text { primarily Pyrenean oak (Quercus pyrenaica) }\end{array}$ \\
\hline & $\begin{array}{l}\text { All formations of sclerophyllous tree species } \\
\text { primarily Holm oak (Quercus ilex subsp. bal- } \\
\text { lota) }\end{array}$ \\
\hline & Mountain pine Forest (Pinus sylvestris) \\
\hline \multirow[t]{3}{*}{ SCRUB } & $\begin{array}{l}\text { High altitude shrubland (Cytisus oromediter- } \\
\text { raneus) }\end{array}$ \\
\hline & $\begin{array}{l}\text { Scrubland with gum cistus (Cistus ladanifer), } \\
\text { lavender (Lavandula stoechas) thyme (Thy } \\
\text { mus sp.) and broom (Retama spaherocarpa) }\end{array}$ \\
\hline & $\begin{array}{l}\text { Scrub with scattered Holm oak or Pyrenean } \\
\text { oak }\end{array}$ \\
\hline \multirow{4}{*}{ PASTURES } & High-altitude pastures of Festuca curvifolia \\
\hline & Pastures for extensive livestock farming \\
\hline & $\begin{array}{l}\text { Pastures correspond to abandoned agricul- } \\
\text { tural areas and recently colonized by thero- } \\
\text { phyte (fallow land) }\end{array}$ \\
\hline & Pastures with scrub and scattered trees \\
\hline CROPLANDS & Dry farming crops, primarily cereal \\
\hline $\begin{array}{ll}\text { ROCKY AREAS } \\
\text { WITH SCRUB } \\
\text { AND TREES }\end{array}$ & $\begin{array}{l}\text { Granite landscapes covered by scrubs and } \\
\text { trees (Quercus ilex subsp. ballota, Pinus } \\
\text { sylvestris, Juniperus communis). }\end{array}$ \\
\hline \multicolumn{2}{|l|}{ RESERVOIRS } \\
\hline $\begin{array}{l}\text { AREAS UNDER } \\
\text { URBAN DEVEL- } \\
\text { OPMENT }\end{array}$ & $\begin{array}{l}\text { Areas in first stages or with low density of } \\
\text { urbanization. }\end{array}$ \\
\hline URBAN AREAS & Consolidated urban areas \\
\hline
\end{tabular}

1980 (Table 2) land uses making up the landscape of this territory (scrub and rocky areas with scrub and trees) are associated with the PNA. However, croplands, pastures and urban areas are preferentially associated with the surrounding area. This fact highlights, on one hand, the value of the traditional agricultural systems remaining in the peripheral area of the PNA, and on the other, the incipient deterioration of rural areas lying closer to urban settlements, which become barren land in the following decades.

The $\chi^{2}$ results in 2001 indicate that, throughout the study period, the land uses that led to the PRCAM being protected have persisted. However, only urban areas are associated with the surrounding area, probably as a result of the different types of management inside and outside the PNA.

\subsection{Boundary effect on territorial dynamics}

We identified five types of territorial dynamics: urban development, scrub encroachment, forest encroachment, new pastures -created by clearing forest and scrub, or resulting from abandonment of croplands- and new crops -resulting from new agricultural activities- (Figure 5 and Table 3). These dynamics affect $20.5 \%$ of the area of the PRCAM and $26.02 \%$ of the surrounding area [33].

Most of these dynamics are the consequence of a process of abandonment of traditional activities or of an increase in urbanised areas, as generally occurs in many parts of the Madrid Regional Autonomy. Some, such as forest encroachment or scrub encroachment, occur preferentially in areas that are no longer exploited for agriculture. The new 
Table 2. Land uses in the PRCAM and surrounding area in 1980 and 2001. Significant values of the $\chi^{2}$ analysis are highlighted $(p<0.05)$.

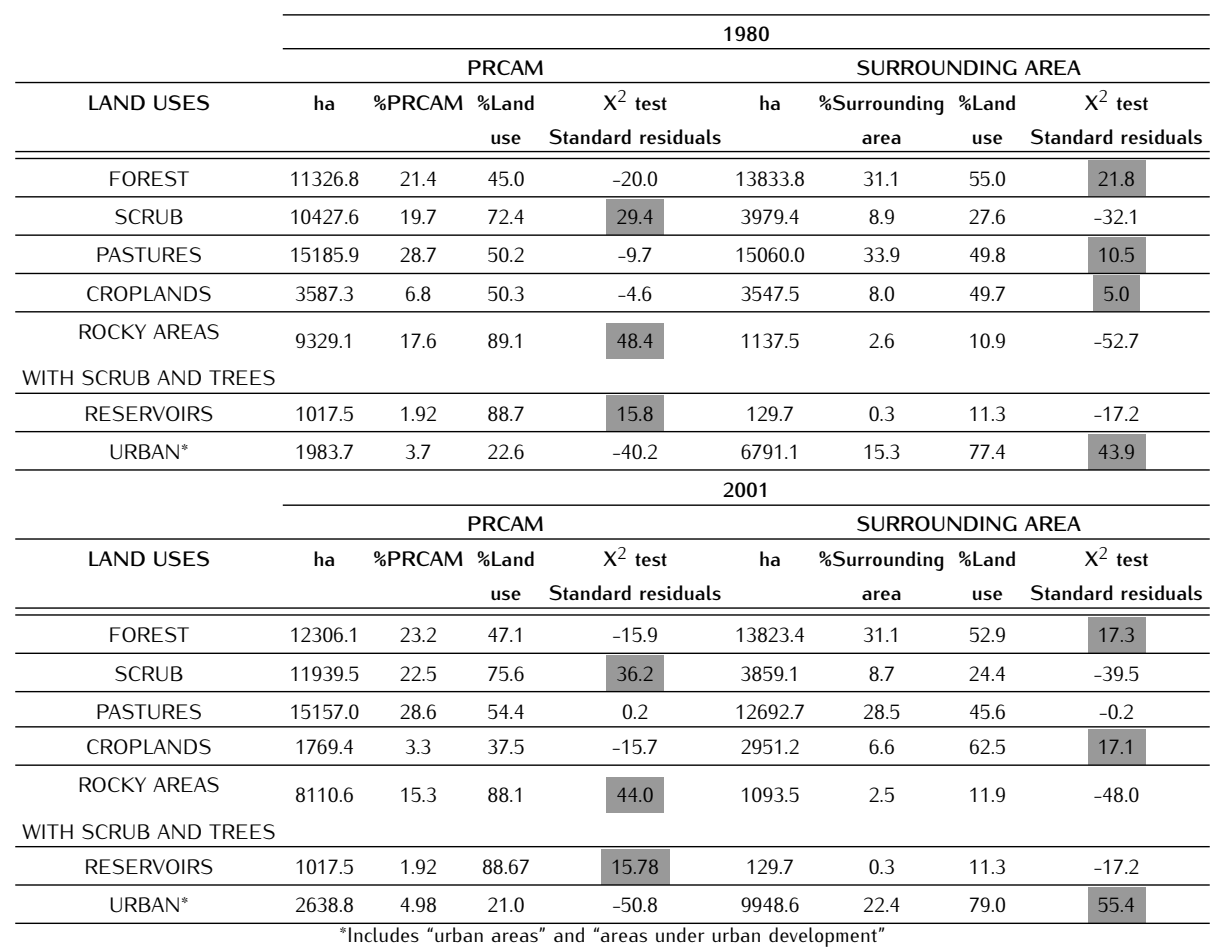

Table 3. Changes matrix identified in the PNA from 1980 to 2001. FE: Forest Encroachment; SE: Scrub Encroachment; NP: New Pastures; NC: New Crops; URB: Urban Development; $\mathbf{N C h}$ : No Change.

\begin{tabular}{|c|c|c|c|c|c|c|c|}
\hline 20011980 & Forest & Scrub & Pastures & Croplands & $\begin{array}{c}\text { Rocky areas } \\
\text { with scrub and trees }\end{array}$ & $\begin{array}{c}\text { Areas under } \\
\text { urban development }\end{array}$ & Urban areas \\
\hline Forest & $\mathrm{NCh}$ & $\mathrm{SE}^{*}$ & NP & & & & URB \\
\hline Scrub & $\mathrm{FE}$ & $\mathrm{NCh}$ & NP & & & & URB \\
\hline Pastures & $\mathrm{FE}$ & SE & $\mathrm{NCh}$ & NC & & & URB \\
\hline Croplands & $\mathrm{FE}$ & & NP & $\mathrm{NCh}$ & & & URB \\
\hline $\begin{array}{c}\text { Rocky area } \\
\text { with scrub and trees }\end{array}$ & FE & SE & & & $\mathrm{NCh}$ & & URB \\
\hline Areas under urban development & & SE & & & & $\mathrm{NCh}$ & URB \\
\hline Urban areas & & & & & & & Nch \\
\hline
\end{tabular}

pastures are also mainly the result of this abandonment process (Table 3). Nonetheless, in some sectors, marginal crop cultivation can be found. The urban development observed is located at the southeast and southwest areas of the park near to the city of Madrid (Figure 4). This is a consequence of the growth of the city of Madrid and its surrounding metropolitan area and its transport infrastructures in the last decades. All this mentioned above constitutes a hazard to the spatial and temporal continuity inside and outside the PNA [7, 16, 34].

In the PRCAM and the surrounding area, a high percent- age of the vegetation or land uses $79.5 \%$ and $73.98 \%$, respectively) remained conserved from 1980 to 2001 (called "no change"). The $\chi^{2}$ analysis, however, indicates that the "no change" is significantly associated with the park (Table 4).

If we observe the change percentages in the PRCAM, we will find no predominant dynamics. According to the $x^{2}$ analysis, however, new crops, forest encroachment and new pastures are significantly associated with the protected area, constituting over $60 \%$ of the total change (Table 4). 


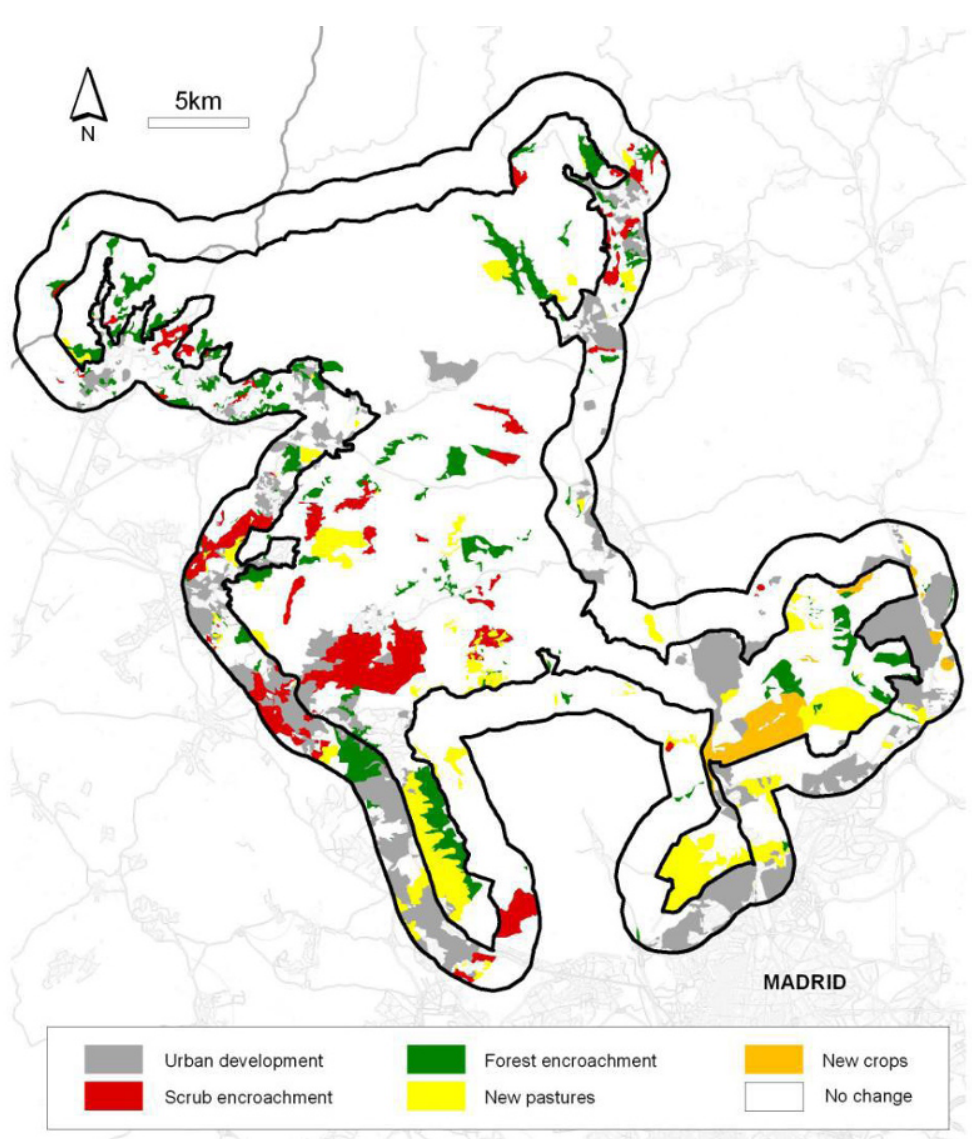

Figure 5. Location of territorial dynamics in the PRCAM and in the surrounding area.

On the contrary, in the surrounding area the predominant dynamic is urban development $(16.10 \%$ in this area compared with $3.2 \%$ in the PRCAM). The $\chi^{2}$ analysis confirms the association between this dynamic and the surrounding area (Table 4). The urban development dynamic in relation to the total area that has changed rises to $62 \%$. In the park this dynamic is the consequence of the densification and consolidation of urban settlements that already existed in 1980, as opposed to the appearance of new urbanised areas.

In 2001, no new areas under urban development were identified within the protected area, unlike what occurred in the surrounding area (Figure 3). The urban development outside the PNA is merely an example of what has been occurring in Madrid as well as in the rest of Spain [35] and in other parts of Europe [22] in the last decades.

Our results indicate the existence of a boundary effect caused by the different frequency distribution of types of dynamics between the PRCAM and the surrounding area, more noticeable in the case of the urban dynamic. This involves alterations in the ecological functioning of the territory: changes at local and regional scale, new spatial pattern, habitat fragmentation, loss of connectivity and loss of biodiversity $[34,36,37]$. Protection against urban development should be extended beyond the boundaries of the PNA in order to avoid deterioration [5].

We have observed an increase in urban demand in areas lying next to PNA, as people consider that proximity to these enclaves with high natural values, improves inhabitants' quality of life $[16,38]$. This prevents the establishment of peripheral protection belts intended to serve as buffers for protecting environment and landscape against negative effects of chemical pollutants, urban heat islands or the improved access for visitors to natural areas provided by road networks [39]. The ultimate result of this boundary effect is a "mosaic type" model of territorial organisation in which the protected areas are fenced in, lacking any continuity, by areas presenting abundant urban uses and infrastructures.

Thus, demarcation of a PNA, despite attempting to conserve the integrity of a territory, would generate great 
Table 4. Territorial dynamics in the PRCAM and in the surrounding area from 1980 to 2001. Significant values of the $\chi^{2}$ analysis are highlighted $(p<0.05)$.

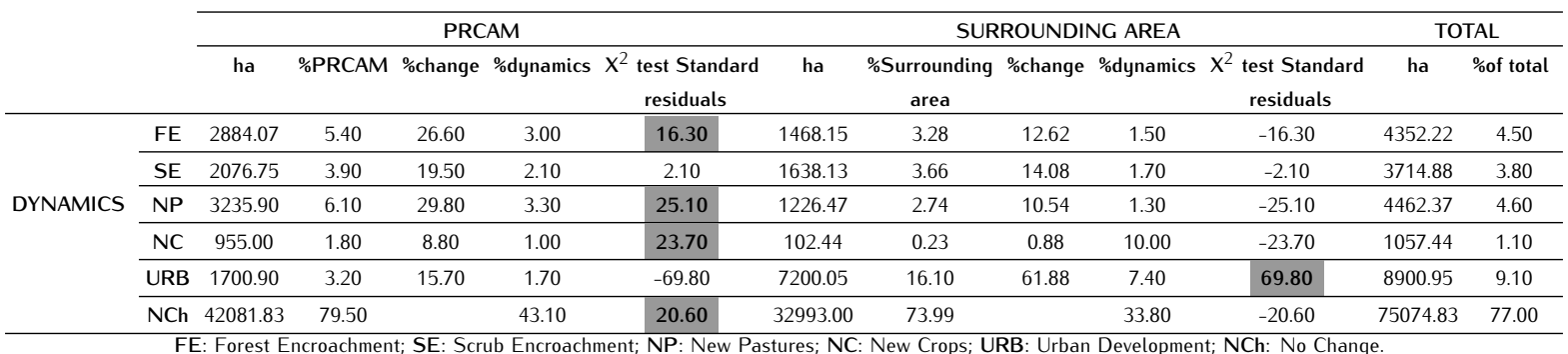

territorial tension due to the proliferation of aggressive and irreversible uses and a totally differentiated management model for the neighbouring areas. Consequently, the existence of a PNA as a tool for protecting a territory's environmental values is insufficient with regard to minimising the effects of the predominant urban processes. Some authors $[40,41]$ therefore consider that protection laws ought to be established for areas lying beyond the boundaries of protected areas that present similar conservation values. So, it is necessary to incorporate the PNA into the land use planning [5].

The dynamics we detected relating to agricultural abandonment and urban sprawl reflect a tendency towards loss of landscape heterogeneity. It also leads to the loss of the former balanced dynamics of traditionally maintained agrosilvopastoral activity, which has very much contributed to the biological diversity, productivity, stability and scenic attractiveness of these typical landscapes of Mediterranean environments [34, 42-44].

\section{Conclusions}

The results obtained show differences in composition of land uses and territorial dynamics, along with a boundary effect between the PNA and the surrounding area. This boundary effect is more evident in land uses related to abandonment of agriculture and the urban use of the territory. With regard to dynamics, forest encroachment, new crops and new pastures are characteristic of PRCAM. Furthermore, the surrounding area is fundamentally characterised by urban dynamics.

The proximity to the city of Madrid and its metropolitan area has an evident effect on the dynamics of PRCAM and possibilities of spatial and temporal continuity. These effects include a decrease in productive land and in plant cover, modifications of surface water and groundwater flows, generation of urban heat environments and increased waste and spillage [39]. In turn, the habitats of numerous species are altered or fragmented. Species composition in the park can be affected, as exchanges of material and energy exist between a PNA and its peripheral area, including plant and animal species that move from one place to another [37, 45]. Consequently, with regard to conservation, processes taking place outside a PNA are just as important as what occurs inside it. Although the criteria employed for protecting these areas are valid and socially acceptable, the real significance of these connections should also be taken into consideration. Conserving determined ecosystems within a PNA does not guarantee its protection. Safeguarding the surrounding area is fundamental for providing connectivity between protected areas and ensuring conservation based upon coherent land planning that is consequential with this objective and with maintenance of environmental goods and services $[46,47]$. Protection of the values contained in this PNA should therefore be complemented by conservation and monitoring of its natural values beyond the established boundaries.

\section{References}

[1] IUCN (Internatonal Union for Conservation of $\mathrm{Na}$ ture), The Durban Action Plan, $V^{\text {th }}$ IUCN World Parks Congress, Durban (The South African Republic), 2003

[2] Baeza A., Estades C., Effect of the landscape context on the density and persistence of a predator population in a protected area subject to environmental variability. Biol. Conserv., 143, 2009, 94-101

[3] Chape S., Blyth S., Fish L., Fox P., Spalding M., (Compilers), United Nations List of Protected Areas, IUCN, Gland, Switzerland and Cambridge, UK and UNEP-WCMC, Cambridge, UK, 2003

[4] Gómez S., Componentes del valor del paisaje mediterráneo y el flujo de servicios de los ecosistemas (The components of the Mediterranean landscape value and the flow of ecosystem services), Ecosistemas, 16, 
2007, 97-108 (Abstract in english. Full text in spanish)

[5] Gordon A., Simondson D., White M., Moilanen A., Bekessy S.A., Integrating conservation planning and land use planning in urban landscapes. Landscape Urban Plan., 91, 2009, 183-194

[6] Bennett G., EECONET: Towards a European Ecological Network. Institute for European Environmental Policy, Arnhem, Holland, 1991

[7] Bennett A.F., Linkages in the landscape. The role of corridors and connectivity in wildlife conservation, IUCN, Gland, Switzerland, 2003

[8] Múgica M., De Lucio J.V., Martínez C., Sastre P., Atauri J.A., Montes C., Territorial integration of natural protected areas and ecological connectivity within Mediterranean landscapes. Consejería de Medio Ambiente, Junta de Andalucía, Sevilla, 2002

[9] Woodroffe R., Ginsberg J.R., Edge effects and the extinction of populations inside the protected areas. Science, 280, 1998, 2126-2128

[10] Farina A., The Cultural Landscape as a Model for the Integration of Ecology and Economics. BioScience, 50, 2000, 313-320

[11] Ogada M.O.; Woodroffe, R.; Oguge, N.O. \& Frank L.G., Limiting depredation by African carnivores: the role of livestock husbandry. Biol. Conserv., 17, 2003, 1521-1530

[12] Baskett M.L., Micheli F., Levin S.A., Designing marine reserves for interacting species: insights from theory. Biol. Conserv., 137, 2007, 163-179

[13] Olupot W., Barigyira R., Mcneilage A.J.,Edge-related variation in medicinal and other "useful" wild plants of Bwindi Impenetrable National Park, Uganda. Conserv. Biol., 23, 2009, 1138-1145

[14] Cody L.M., Diversity, rarity, and conservation in Mediterranean-climate regions. In: M.E. Soulé (Ed.), Conservation Biology: The Science of Scacity and Diversity, Sinauer, Sunderland, 1986, 122â€Ș152

[15] Carey C., Dudley N., Stolton S., Squandering paradise? The importance and vulnerability of the world's protected areas, World Wildlife Fund for $\mathrm{Na}$ ture International, Gland, Switzerland, 2000

[16] EEA (European Environmental Agency) Urban sprawl in Europe. The ignored challenge, European Environment Agency, 10, Copenhagen, 2006

[17] Bennett G., Integrating biodiversity conservation and sustainable use: lessons learned from ecological networks, IUCN, Gland, Switzerland, 2004

[18] Forman R. T. T., Godron M., Landscape ecology, Wiley, New York, 1986

[19] Forman R.T.T., Land mosaics, Cambridge University press, Cambridge, 1995
[20] Ishe M., Swedish agricultural landscapes-patterns and changes during the last 50 years, studied by aerial photos. Landscape Urban Plan., 31, 1995, 2137

[21] Olsson E.G., Austrheim G., Grenne S.N., Landscape change patterns in mountains, land use and environmental diversity, Mid-Norway 1960-1993. Landscape Ecol., 15, 2000, 155-170

[22] Moreira F., Rego F.C., Ferreira P.G., Temporal (19581995) pattern of change in a cultural landscape of north-western Portugal: implications for fire occurrence. Landscape Ecol., 16, 2001, 557-567

[23] Feranec J., Kopecka M., Vatseva R., Stoimenov A., Otahel J., Betak J., Husar K., Landscape change analysis and assessment (case studies in Slovakia and Bulgaria). Cent. Eur. J. Geosci., 1, 2009, 106-119

[24] Esri, Environmental System Research Institute, Inc., ArcView 3.2 Vector and Raster GIS Analysis Tool, USA, 2009

[25] Ramos A., Formaciones vegetales y usos actuales del suelo de Madrid. Memoria y Mapa (Plant formations and current land-uses in Madrid (Report and Map). Consejería de Agricultura y Ganadería, Comunidad de Madrid, Escala 1:200.000, 1985 (in Spanish)

[26] Comunidad de Madrid, Descripción de unidades de vegetación: clasificación sistemática. Mapa de Vegetación 1997, Consejería de Medio Ambiente. Comunidad de Madrid, 1997 (in Spanish)

[27] Muñoz C.; Gil T.; De Las Heras P. González N., Memoria del mapa de vegetación de la Sierra de Guadarrama (Vertiente Madrileña) (Report and Vegetation Map of Guadarrama Range [Madrid side]). Informe Técnico Centro de Investigaciones Ambientales de la Comunidad de Madrid, 2004

[28] IUCN, Guidelines for protected areas management categories, CNPPA and WCMC, IUCN, GLAND, Switzerland and Camdbrige, UK, 1994

[29] Gómez-Sal A., Belmontes J.A., Nicolau, J.M., Assessing landscape values: a proposal for a multidimensional conceptual model. Ecol. Model., 168, 2003, 319-341

[30] De Miguel J.M., Naturaleza y configuración del paisaje agrosilvopastoral en la conservación de la diversidad biológica en España (Nature and configuration of agricultural-forestry-pasture landscape in the conservation of biological diversity in Spain). Rev. Chil. Hist. Nat., 72, 1999, 547-557

[31] Gómez-Sal A., Álvarez J., Muñoz-Yanguas M.A., Rebollo $S$., Patterns of change in the agrarian landscape in the area of the Cantabrian Mountains (Spain) Assessment by transition probabilities. In: Bunce R.G.H., Ryszkowski L., Paoletti M.G. (Eds.) Land- 
scape ecology and agrosystems, Lewis Publishers, Boca Raton, USA, 1993

[32] González Bernáldez F., Rey Benayas J.M., Levassor C., Peco B., Landscape ecology of uncultivated lowlands in Central Spain. Landscape Ecol., 3, 1, 1989, 3-18

[33] De las Heras P., Fernández-Sañudo P., López Estébanez N., Roldán Martín M.J., Landscape dynamics in a protected natural area "Cuenca Alta del Manzanares" Regional Park (Madrid, Spain), Extended Abstracts from The Permanent European Conference for the Study of the Rural Landscape, European Rural Future: Landscape as an Interface, 2007 http://www.geog.fu-berlin.de/ ${ }^{\text {pecsrl/index.html }}$

[34] Jongman R.H.G., Homogenisation and fragmentation of the European landscape: ecological consequences and solutions. Landscape Urban Plan., 58, 2002, 211221

[35] Observatorio de la Sostenibilidad de España (OSE), Cambios de ocupación del suelo en España. Implicaciones para la sostenibilidad (Changes in land occupation in Spain and its implications for sustainability), Madrid, 2006 (in Spanish)

[36] Hilty J.A., Lidicker Jr. W.Z., Merendender A.M., Corridor Ecology: the science and practice of linking landscapes for biodiversity conservation. Island Press, Washington, DC, 2006

[37] Fernández-Sañudo P., Gil T., Fragmentation effects on the state of conservation of forest and shrub ecosystems in "Sierra de Guadarrama" future National Park (Madrid, Spain). In: Smithers R. (Ed.): Proceedings of the $12^{\text {th }}$ annual IALE (International Association for Landscape Ecology) conference "Landscape ecology of trees and forests", Cirencester, UK, 2004, 355-356

[38] Voth A., National parks and rural development in Spain. In: Mose I. (Ed.), Protected areas and regional development in Europe - Towards a new model for the 21 st century. Ashgate, Aldershot, England, 2007, 141-160

[39] Barreiro M.M., Tripler C.E., Forest remnants along urban-rural gradients: examining their potential for global change research. Ecosystems, 8, 2005, 568582

[40] Mcneely J.A., Protected areas for the 21st century: working to provide benefits to society. Biodivers. Conserv., 3, 1994, 390-405

[41] Halladay P., Gilmour D.A., Conserving Biodiversity Outside Protected Areas: The Role of Traditional Agro-Ecosystems, Gland, Switzerland, IUCN, 1995

[42] Stanners D., Bourdeau P. (Ed.), Europe's environment. The Dobrís assessment. European Environment Agency, Copenhagen, 1995

[43] Washer D., Múgica M., Gulinck H., Establishing targets to assess agricultural impacts on European landscapes. In: Brower F., Crabtree R. (Eds.), "Environmental indicators and agricultural policy". CABI Publishing, The Hague, 1999, 73-87

[44] Sastre P., Guillén D.F., Cereal steppes in Central Spain. In: Buguñá Hoffman L. (Ed.), Agricultural functions and biodiversity - A European stakeholder approach to the CBD agricultural biodiversity work program, European Centre for Nature Conservation, Tilburg, 2001

[45] Fernández-Sañudo P., Gil T., Study of the effect of the transportation infrastructures on habitats fragmentation in the future National Park "Sierra de Guadarrama" (Madrid, Spain). IENE (Infra Eco Network Europe) Conference 2003, Proceedings of the "International conference on habitat fragmentation due to transportation infrastructure". Institute of Nature Conservation, Brussels, Belgium, 2003, http://www. iene.info

[46] Costanza R., D'arge R., De Groot R., Farber S., Grasso M., Hannon B., Limburg K., Naeem S., et al., The value of the world's ecosystems services and natural capital. Nature, 387, 1997, 253-260

[47] De Lucio Fernández J.V., Atauri Mezquida J.A., Sastre Olmos P., Martínez Alandi C., Conectividad y redes de espacios naturales protegidos: del modelo teórico a la visión práctica de la gestión (Connectivity and networks of natural protected areas: from the theoretical model to the practical view of management). In: García Mora R. (coordinator) Conectividad ambiental: las áreas protegidas en la cuenca mediterránea (Environmental connectivity: protected areas in the Mediterranean context), Consejería de Medio Ambiente. Junta de Andalucía, Spain, 2003, 29-53 